\title{
МОНГОЛ УЛСЫН ШИЛЖИЛТИЙН ЭДИЙН ЗАСАГ, ЦААШДЫН ТөсөөлӨЛ
}

Академич Т.Намжим

Монгол улсад нийгэм-эдийн засгийн өөрчлөлт шинэчлэлт явагдаж, шинэ тогтолцоонд шилжих оролдлого хийсээр даруй 20-иод жилийн хугацаа өнгөрлөө.

Шилжилтийн үеийн эдийн засгийн асуудлыг авч үзэхийн өмнө юуны түрүүнд ер нь Монгол улсын хувьд шилжилтийн үеийн мөн чанар, шийдвэрлэх зорилт, үндсэн асуудлын агуулга, дуусах хугацаа, түүний шалгуур гэх зэрэг зүйлийн талаар товч боловч санаа бодлоо толилуулах нь зүйтэй юм.

Шилжилтийн ve. Нилээн хэдэн жилийн өмнөөс шилжилтийн үе дуусч буй учраас "цэглэх цаг болсон" гэхчлэн ярих бичих явдал байсан билээ. Энэ талаар нэгэн баримтыг дурьдах аваасу, Монгол Улсын Ерөнхийлөгчийн 1997 оны сонгуульд өрсөлдөгч П.Очирбат өөрийн сонгуулийн сурталчилгаанд зориулж, “Энэ жилийн хавар манай ард түмний хувьд шилжилтийн үеийг цэглэх, амьдралын доройтлыट арилгах, шинэ хөгжлийн хавар болно гэдэгт Та бүхний мэргэн сонголт бүрнээ хэрэгжиж эхлэх хавар байна гэдэгт би Төрийн тэргүүний хувьд итгэлтэй байна" гэсэн бичээсийг ард нийтэд тараасан байдаг юм.

Тэрхүү үгүүлбэр нь Монгол улсын шинэтгэл, шилжилтийн бүр эхэн үеэс буюу 6 жил төр улсыг тэргүүлж байсан бие хүний бодлоор хэлэгдэж, гараар бичигдсэн зүйл байсан учраас бидний анхааралд аргагүй өртсөн хэрэг болой. Уг бичлэгийн агуулга бол Монгол улс зах зээлийн тогтолцоонд шилжих үйл явцыг ердөө л тухайн 1997 оны хавар Ерөнхийлөгчийн сонгууль явагдсан тэр нэгэн хаврын улиралд гэнэтхэн цэглэчих буюу дуусгавар болох тухай нэн хачирхалтай эндүү ойлголтыг олон түмэнд хүрэгсэн байв.

Тийм байдал нь тухайн үед Монгол улсын төр засгийн дээд түвшиндшилжилтийн үеийн шийдвэрлэх зорилт, үндсэн асуудлын агуулга, шалгуурын талаар онол, практикийн ямар ч тодорхойлолт, ойлголт байгаагүй болохыг гэрчилсэн хэрэг юм.

Илтгэгч хүмүүн миний бие 1990 оны эхэнд эдийн засгийн зах зээлийн тогтолцоонд шилжих асуудлаар бичиж нийтлүүлсэн “Зах зээлийн зөрөг зам” хэмээх номондоо болон Монгол улсын 1990-2000 оны хоорондохь нийгэм-эдийн засгийн байдалд дүн шинжилгээ хийж, 2003 онд нийтлүүлсэн “Монголын өнөө ба хойч - Өнөөгийн ухаарал, хойчийн бодол” хэмээх номондоо шилжилтийн үеийн гол агуулга, мөн чанар, үе шат, шийдвэрлэх зорилт, шалгуурыг томъёолон тодорхойлох оролдлого хийсэн юм.

Шилжилтийн үеийн гол агуулга, мөн чанарыг товчхон байдлаар хураангуйлан томъёолохдоо, нэгд, зах зээлийн тогтолцооны хууль, эрх зүйн үндсийг оновчтой байдлаар бүрдүүлэх, хоёрт, шинэ тогтолцооны бүхий л арга механизмыг зохистой хэлбэрээр зүгшрүүлэх, макро түвшингийн үзүүлэлт, үйл явц тогтворжсон байх, гуравт, эдийн засгийн тогтвортой өсөлтийн баттай эх суурь тавигдсан байх зэргийг гол агуулга, шалгуур болгон авч үзэх саналыг дэвшүүлсэн юм.

Түүнчлэн дээр дурьдсан ном бүтээлдээ шилжилтийн үеийн шийдвэрлэх үндсэн асуудлыг 16 зүйлээр авч үзсэн байгаа болно.

Өнгөрсөн хориод жилийн хугацаанд дээр дурьдсан шинэтгэл шилжилтийн үндсэн асуудлуудыг хэрэгжүүлэх үйл хэрэг явагдаж ирсэн нь мэдээжийн хэрэг юм. 
Гэвч дээрх бүхий л асуудлыг анхнаасаа иж бүрнээр нь үндэслэл тооцоотой боловсруулж, тогтвортой хэрэгжүүлж байх талаар учир дутагдалтай байсан юм.

Шилжилтийн хугацаанд Монголын төр засгийн дээд байгууллагын бие бүрэлдэхүүн ойр ойрхон солигдсон, улмаар улс төрийн намуудын төр засгийн эрх мэдлийн төлөөх тэмцэл сөргөлдөөний явцд тэдний бодлого чиглэл, арга барил, ашиг сонирхол ч мөн дагаж өөрчлөгдөж байсан учраас эдийн засаг, нийгмийн шинэтгэлийн бүрдэл хэсэг нэг бүрийг, тэдгээрийн мөн чанар, үндсэн агуулга, арга механизм, нөлөө хамаарал, үр өгөөж, хэрэгжүүлэх хэлбэрийн үүднээс аль болох нарийвчилсан үндэслэлтэйгээр амьдрал ахуйд ажил хэрэг болж төлөвших хэмжээнд боловсруулах, нийгмийн сэтгэл зүйн таатай орчин, хууль эрх зүйн баттай үндсийг бүрэлдүүлэх, хяналт зохицуулалтаар хангах, хүн ардаa сургаж туршлагажуулах зэрэг олон арга ажиллагаа төдийлэн хангалттай бус байв.

Түүнчлэн анхнаасаа зах зээлийн тогтолцоонд шилжих арга тактик, үе шатыг тоймлож тогтоогоогүй, тийм болохоор үе шаталсан үйл хэргийн хөтөлбөр боловсруулаагүй, ерөнхийдөө урсгалын байдалтай явагдаж ирсэн юм.

Мөн илтгэгч хүмүүн би бээр зах зээлийн тогтолцоонд хэрхэн шилжих арга тактик, үе шатны талаар 1990 онд “Үнэн” сонинд нийтлүүлсэн цуврал үгүүлэл, мөн онд бичиж нийтлүүлсэн “Зах зээлийн зөрөг зам” номонд болон Монголын эдийн засагчдын зөвлөлгөөнд (1991 оны эхээр) "Монгол улсын эдийн засгийн харилцааг өөрчлөн шинэчлэх асуудалд" сэдэвээр хэлсэн үг, улмаар 1991 оны хавар Москва хотноо болсон Монгол, Зөвлөлтийн эрдэмтэдийн дугуй ширээний уулзалтад тавьсан "Улс орны эдийн засгийн аюулгүй байдлын шалгуур, үзэл баримтлал" нэртэй илтгэл зэрэг ном, үгүүлэл, илтгэлд Монгол улсын зах зээлийн тогтолцоонд шилжих үйл хэргийг 6 үе шатаар явуулах, мөн шилжилтийн бэлтгэлийг 5 чиглэлээр хангах санал зөвлөмжийг дэвшүүлсэн билээ.

Түүнчлэн зах зээлийн тогтолцоонд шилжихэд Монголын тухайн үеийн нөхцөл байдлын улмаас нийгэм-эдийн засагт учирч болзошгүй сөрөг үр дагавар, хүндрэл бэрхшээл, тэдгээрийг саармагжуулах арга замын талаар 4 зүйлийн анхааруулгыг толилуулж байсан юм.

Гагцхүү харамсалтай нь тухайн тэр цаг үед төр засгийн эрхэнд гарсан хүмүүс бодит цэгнэл ухаарлаа алдаж, хийрхэл туйлшралаар хөөрцөглөх, хийсвэр ойлголтоор төөрөлдөх, хуурмаг мэдэмхийрэлээр ташаарах, худал амлалтаар аргацаах байдалтай байсан тул бусдын санал зөвлөмжийг сонсох, тунгаан бодох сөхөөгүй болсон байж билээ. Тийм нөхцөл байдалд бидний санал зөвлөмж анзааргагүй өнгөрсөн юм.

Гэтэл тухайн үедээ улс нийгмийн өмчд тулгуурласан, төвлөрсөн төлөвлөгөөт эдийн засгийг тухайн үеийн монголчуудын сайн таньж мэдээгүй байсан зах зээлийн өвөрмэц орчинд шилжүүлэх явдал нь туйлын нарийн төвөгтэй, шинэ мэдлэг, арга туршлага шаардах үйл явц байсан билээ.

Монгол улсад 1990 оны эхэнд төр засгийн удирдлагад гарсан бодит мэдлэг, зөв ухаарал дутмаг зарим хүмүүс анхнаасаа эдийн засгийн удирдлага, зохицуулалтын арга механизмыг хэрхэн өөрчлөн шинэчлэх, зах зээлийн тогтолцоонд ямар арга хэлбрээр шилжих болон шинэ нөхцөл байдалд бодит эдийн засгийг цаашид хөгжүүлэх арга замыг тодорхойлох талаар чиг баримтлал, мөрийн хөтөлбөрийг цэгнэл үндэслэлтэй бодож боловсруулахын оронд улс орны эдийн засгийг зүгээр л төрийн зохицуулалтгүй болгочихвол зах зээлийн сайн тогтолцоо аяндаа бүрэлдээд хөгжил дэвшлийг ундруулаад өгнө гэсэн хөнгөн хуумгай ойлголтоор хандсан юм. 
Эдүгээ шилжилтийн үе дууссан, эсэх талаар Төр засгийн дээд түвшиндээ болон шинжлэх ухааны хүрээнд цогц шалгуур, үндэслэл гаргаж дүгнэлт хийж байгаа явдал гараагүй байна.

Шилжилтийн уеийн эдийн засаг. Өнөө үед шилжилтийн эдийн засгийн байдалд шинжлэхүй ухааны арга зүйн дагуу дүн шинжилгээ хийх, улмаар цаашдын хөгжил дэвшлийн арга зам, бодлого зорилтыг тодорхойлох, төсөөлөл хөтөлбөрийг боловсруулах явдал нэн чухлаар шаардагдаж байна.

Эдүгээ цаг үеийн өндөрлөгөөс эргэн авч үзэх аваасу, манай оронд өмч хувьчлалыг буруу арга хэлбэрээр, сайтар бодож үзэхгүйгээр, яаран сандран явуулсанаар урьд өмнө нь улсын ихээхэн хэмжээний хөрөнгө зардлаар, ард олны хөдөлмөр зүтгэлээр бүтэж бүрэлдсэн үйлдвэр, аж ахуйн газруудыг үрэн таран хийж, эдийн засгийн потенциалд асар их сүйтгэлийг учруулсан билээ.

Аж үйлдвэрийн салбарын хувьд 1990-ээд оны эхэн үеийн өмч хувьчлалын явцд хөнгөн аж үйлдвэрийн салбарт ноолуурын үйлдвэрээс бусад малын гаралтай түүхий эд боловсруулдаг болон оёдлын олон үйлдвэрүүд, мөн металл боловсруулах хэдэн үйлдвэрүүд устаж байхгүй болсон.

Хөдөө аж ахуйн салбарт, газар тариалангийн аж ахуйнууд, малын тэжээл тариалалтын болон тэжээлийн үйлдвэр, цехүүд, үхрийн саалийн фрермүүд, гахай шувууны аж ахуйнууд, усны аж ахуйн барилга байгууламжийн газрууд цөм байхгүй болсон. Түүнчлэн авто тээврийн ачаа тээвэрлэлтийн олон томоохон авто паркийн аж ахуйнууд мөн тарж үгүй болсон байв.

Тийм учраас 1995 он гэхэд 1990 оны өмнөх үеийнхээс дотоодын нийт бүтээгдэхүүн 16 хувиар, үндэсний нийт бүтээгдэхүүн 13 хувиар, аж үйлдвэрийн нийт бүтээгдэхүүн 35 хувиар, хөдөө аж ахуйн нийт бүтээгдэхүүний хэмжээ 10 хувиар тус тус буурсан, 2000 он гэхэд ч эдийн засгийн макро түвшингийн эдгээр үзүүлэлтийн бууралтыг нөхөж чадаагүй, мөн л 1989 оныхоос 3-30 хувиар доогуур байсан юм. Энэ байдал нь дараахь хүснэгтийн өгөгдөхүүнээс тодорхой байгаа болно.

Шилжилтийн эхний арван жилийн эдийн засгийн макро түвшингийн Хүснэгт 1. үндсэн үзүүлэлтийг таван жилийн эцсийн зэрэгцүүлэх үнээр тооцож 1989 оныхтой харьцуулсан байдал, хувиар

\begin{tabular}{llllll}
\hline \multicolumn{1}{c}{ Үндсэн үзүүлэлт } & 1989 & 1990 & 1993 & 1995 & 2000 \\
\hline Дотоодын нийт бүтээгдэхүүн & 100 & 97.5 & 52.2 & 84.4 & 97.2 \\
- Нэг хүнд ноогдох ДНБ & 100 & 94.8 & 70.7 & 76.4 & 82.1 \\
Үндэсний нийт орлого & 100 & 97.4 & 80.7 & 88.6 & 108.0 \\
- Нэг хүнд ноогдох ҮНО & 100 & 94.9 & 73.4 & 83.6 & 91.3 \\
Аж үйлвэрийн нийт бүтээгдэхүүн & 100 & 94.3 & 57.6 & 64.7 & 70.7 \\
ХАА-н нийт бүтээгдэхүун & 100 & 96.2 & 80.2 & 90.6 & 93.3 \\
\hline
\end{tabular}

Тайлбар : Энэхүу тооцоонд хэдийгээр 2000 оны үзүүлэлтийट 1995 оны зэрэгцүүлэх үнээр тооцсон боловч биет үзүүлэлтийн өсөлтөөс гадна үнийн өсөлт ихээхэн нөлөөлсөн байгаа болно.

Аливаа улсын хөгжлийн түвшингийн гол хэмжүүр байдаг нэг хүнд ноогдох ДНБий болон ҮНО-ын хэмжээ 2000 онд 1989 оныхоос 9-18 хувиар доогуур байв.

Мөн 1990-2000 оны хугацаанд Монгол улсын эдийн засгийн бүтэцд ноцтой 
ухралт гарсан явдал нь ДНБ-д аж үйлдвэрийн салбарын бүтээгдэхүүн 53 хувийг эзлэж байсан бол 2000 онд 38 хувь болж буурсан, түүнчлэн аж үйлдвэрийн болон хөдөө аж ахуйн нийт бүтээгдэхүүний харьцаа 1980-аад оны сүүлчээр 70:30 гэсэн түвшинд хүрээд байсан бол 1995 онд 40:60, 2000 онд 46:54 болж аж үйлдвэрийн бүтээгдэхүний хэмжээ, хувь ихээхэн буурч, тэр харьцаагаар хөдөө аж ахуйнх өссөн байв. Энэ нь Монгол улсад аж үйлдвэржилт давамгайлсан бүтэц бүхий эдийн засагтай болох зарчмын зорилт 1980-аад оны сүүлч гэхэд хэрэгжсэн байснаа зах зээлийн тогтолцоонд шилжсэн эхний арван жилд алдагдсан байлаа.

ОХУ-ын нэрт монгол судлаач эрдэмтэн, доктор, профессор В.В.Грайворонский “Реформы в социальной сфере современной Монголии" (Москва, 2007 он) хэмээх номондоо “Т.Намжимын энэ дүгнэлтийг хүлээн зөвшөөрөхөөс өөр аргагүй юм" гэж тэмдэглэжээ.

Монгол улсын шилжилтийн үеийн эдийн засгийн байдалд 1990-ээд оны эхэн үеэс хийсэн дүн шинжилгээ Т.Намжимын “Монголын эрт ба эдүгээ” (1996), “Монголын аж ахуй, эдийн засаг”, 2 боть (2000), "Монголын өнөө ба хойч” (2003), “Монгол улсын эдийн засаг” 3 боть (2004), мөн “Хөвөрсөн бодол цэгнэл” (2004) номуудад дэлгэрэнгүй тусгагдсан байгаа болно.

Шилжилтийн үеийн хоёр дахь арван жилийн буюу 2001-2010 оны хугацаанд Монгол улсын эдийн засгийн макро түвшингийн байдлыг шинжлэн үзэж, дүгнэлт хийх шаардлага тулгарч байгаа юм.

Шилжилтийн сүүлийн 10 жилийн хугацаанд Монгол улсын эдийн засгийн макро түвшингийн үзүүлэлт харьцангуй өндөр өсөлттэй байлаа. Тухайлбал, дотоодын нийт бүтээгдэхүүний хэмжээ зэрэгцүүлэх үнээр 2005 онд 2000 оныхоос 2 дахин, 2010 онд 2005 оныхоос 3 дахин нэмэгдсэн байна. Дотоодын нийт бүтээгдэхүүний жилийн цэвэр өсөлт 2002-2008 онуудад дундажаар 7.7 \% байсан бол санхүүгийн хямрал тохиосон 2009 онд -1.3\% байсан, 2010 онд $6.1 \%$ байхаар урьдчилсан гүйцэтгэл гарсан байна.

Сүүлийн гурван жилийн байдлаар (2008-2010) авч үзвэл хувийн хэвшилд бүтээгдсэн нэмэгдэл өртгийн хэмжээ ДНБ-д 72.5-73.4 хувийг эзлэж байв.

Нэг хүнд ноогдох ДНБ-ий хэмжээ мөн хоёр таван жилийн хугацаанд зэрэгцүүлэх үнээр 2.0-2.8 дахин өссөн дүн гарч байгаа болно. Нэг хүнд ноогдох ДНБ оны үнээр Дэлхийн банкны тооцооны аргаар 2005 онд 680 орчим ам.доллар байсан бол 2010 онд 2250 ам.доллар болж нэмэгдсэн тооцоо гарч байгаа юм.

Түүнчлэн үндэсний нийт орлого (ҮНО) ч сүүлийн хоёр таван жилд 2.3-2.6 дахин өссөн дүн гарсан байна. Нэг хүнд ноогдох ҮНО-ын хэмжээ оны үнээр 2044 ам.долларт хүрчээ.

Аж үйлдвэр, хөдөө аж ахуйн салбарын нийт бүтээгдэхүүний үйлдвэрлэл ч харьцангуй өндөр өсөлттэй байв. Эдийн засгийн мкро түвшингийн өсөлтийг дараахь хүснэгтээс үзвэл тодорхой болно.

Шилжилтийн сүүлийн арван жилд эдийн засгийн макро үзүүлэлтийн түвшингээр өмнөх үеийн уналтыг нөхөж нилээдүй давсан дүн харагдаж байгаа боловч ДНБ-ий салбарын бүтцийг авч үзвэл, 2010 оны байдлаар аж үйлдвэрийн салбар $33.4 \%$, хөдөө аж ахуйн салбар 15.9 \%-ийг эзлэж байв. Энэ нь бодит эдийн засгийн хоёр гол салбар ДНБ-д 50 хүрэхгүй хувийг эзлэж байгаа гэсэн хэрэг юм. Тийм байдал нь бүхэлдээ эдийн засгийн бүтэц зохистой бус байгааг, 2005 оноос хойш олигтой өөрчлөлт гараагүй болохыг харуулж байна. 
Шилжилтийн үеийн хоёр дахь 10 жилд эдийн засгийн макро түвшингийн үзүүлэлтийг зэрэгцүүлэх үнээр тооцсон байдал

\begin{tabular}{|c|c|c|c|c|c|}
\hline Үндсэн үзүүлэлт & 2000 & 2005 & 2010 & $\frac{\text { Өсөлтийн х }}{2005 / 2000}$ & $\frac{\text { увь, } \%}{2010 / 2005}$ \\
\hline Дотоодын нийт бүтээгдэхүүн, тэрбум ғ & 632.5 & $1,329.1$ & $4,154.0$ & 210.1 & 312.5 \\
\hline - Нэг хүнд ноогдох ДНБ, мян. Ғ & 264.6 & 527.3 & $1,506.0$ & 199.3 & 285.6 \\
\hline Үндэсний нийт орлого, тэрбум ₹ & 629.1 & $1,440.5$ & $3,771.0$ & 229.0 & 261.8 \\
\hline - Нэг хүнд ноогдох ҮНО, мян.Ғ & 263.2 & 562.2 & $1,357.1$ & 213.6 & 241.4 \\
\hline
\end{tabular}

Тайлбар : Эдийн засгийн макро түвщингийн үзүүлэлтийн тав, таван жилийн өсөлтийн динамикт жил дутмын үнийн өсөлтийн нөлөөг саармагжуулахын тулд 2001-2005 оны үзүүлэлтийг 2000 оны зэрэгцүүлэх үнээр, 2006-2010 оны үзүүлэлтийг 2005 оны зэрэгиүүлэх үнээр тус тус тооцсон болно.

Аж үйлдвэрийн салбарын бүтцийг тусд нь авч үзвэл, 2010 оны статистикийн мэдээгээр, тус салбарын нийт бүтээгдэхүүний үйлдвэрлэлд уул уурхайн олборлох үйлдвэрлэл 66.7 \%, боловсруулах үйлдвэр 23.9 \%, түүний дотор хүнсний бүтээгдэхүүн, ундааны үйлдвэр 10.7 \% , цахилгаан, дулааны эрчим хүч, усан хангамж 9.4 \%-ийг эзлэж байна. Ялангуяа боловсруулах аж үйлдвэрийн салбар ДНБ-д ердөө 8.5 хувийг л эзлэж байна. Энэ нь угаасаа сүүлийн хориод жилд эрдэсийн баяжмалыг боловсруулах үйлдвэр шинээр байгуулагдаагүй, малын гаралтай түүхий эдийг боловсруулах хөнгөн аж үйлдвэрийг сэргээж чадаагүй байгаа явдлаас шалтгаалж байгаа юм. Мөн шилжилтийн хугацаанд металл хайлах, машин техникийн эд анги тоног хэрэгслийн үйлдвэр огт сэргэж бий болсонгүй өнгөрчээ.

Хөдөө аж ахуйн салбарын хувьд 1990-ээд оны эхэн үеэс малын тэжээлийн ургамал тариалалт, өвс тэжээл бэлтгэлийн олон аж ахуйн газруудыг болон тэжээлийн олон арван үйлдвэрүүдийг устгасан, бэлчээр усжуулалтын арга хэмжээг тогтмол далайцтай хэрэгжүүлж чадахаа больсон үндсэн шалтгааны улмаас малын бэлчээр, тэжээлийн хүрэлцээ, хангалт үлэмж доройтсоноос шалтгаалан 1999-2000 оны болон 2009-2010 оны өвөл тохиосон, төдийлэн ноцтой биш зуднаар хоёр удаа 10-11сая мал хорогдсон байна.

Газар тариалангийн салбарын хувьд 1989 оны байдлаар гэхэд 830 мянга орчим га талбайд тариалалт хийж, 840 мянган тонн ургац хураан авч байсан бол 2000 онд тариалалтын талбай 209 мянган га, хураасан ургац 142 мянган тонн болж ихээхэн буурсан байв. Харин сүүлийн үед газар тариалангийн салбарт төр засгаас анхаарал тавьж ажилласны үр дүнд 2010 онд 315 мянган га талбайд тариалалт хийсний үр дүнд нийт хураасан ургацын хэмжээ 355 мянган тонн-д хүрсэн нь 20072008 оныхоос нилээдүй ахицтай болжээ.

Монгол улсад нийгэм-эдийн шинэ тогтолцоонд шилжихийн өмнө ажилгүйдэл байгаагүй бол эдүгээ бодит байдал дээр эдийн засгийн идэвхитэй хүн амын 10 орчим хувь нь ажилгүй байгаа ажээ.

Монгол улсын шилжилтийн үеийн буюу өнөөгийн эдийн засгийн байдалд дүгнэлт хийж үзэх аваасу :

Нэгд, 1990-ээд эхэн үеэс явагдсан өмч хувьчлалын бүтэлгүй үйлдлийн болон тухайн үеийн төр засгийн удирдлага зохицуулалт бүрэн алдагдсаны улмаас тохиосон бодит үйлдвэрлэлийн уналт, устгалыг дагалдсан макро эдийн засгийн 
үндсэн үзүүлэлтийн ноцтой бууралтыг сүүлийн арван жилд нөхсөн, улмаар нилээдүй өндөр өсөлттэй байсан.

Хоёрт, Макро эдийн засгийн үзүүлэлт сүүлийн арван жилд харьцангуй өндөр өсөлтөд уул уурхайн салбарт нүүрс, алт, төмрийн хүдэр зэрэг зарим ашигт малтмалын олборлолт, архи ундаа зэрэг хүнсний зүйлийн үйлдвэрлэл нэмэгдсэн, зэс, алтны олон улсын зах зээлийн үнэ ихээхэн өссөн зэрэг хүчин зүйлс голчлон нөлөөлсөн байна.

Гуравт, Техник, технологийн дэвшлийг дагуулдаг боловсруулах үйлдвэрийг сэргээх, шинээр бүтээн байгуулах талаар олигтой ахиц гараагүй тул эдийн засгийн бүтэцд үйлдвэржилтийн чиглэлээр онцын өөрчлөлт гараагүй байв.

Дөрөвт, Хөдөө аж ахуйн салбарт, 1990 оноос хойш мал сүргийн тоо ихээхэн өсч нэмэгдсэн. Малын тооны өсөлтөд шилжилтийн он жилүүдэд мал, махны экспорт бараг байхгүй болсон явдал голчлон нөлөөлсөн юм. Үндсэн хуульд мал сүрэг бол үндэсний баялаг мөн бөгөөд төрийн хамгаалалтад байна гэсэн заалт хэрэгжээгүй, мал сүргийг төрөөс хамгаалах арга хэлбэр буй болоогүй, холбогдох арга хэмжээг хэрэгжүүлж амжаагүй байгаа тул дээр дурьдсанаар, шилжилтийн хугацаанд тохиолдсон хоёр удаагийн зуданд нийт дүнгээрээ 21 сая мал хорогдсон байв.

Тав, Хүн амын хүнсний хангамжийн нэг гол салбар болох газар тариалангийн салбар шилжилтийн эхэн үеэс бүрэн уналтад орсон байв. Тийм байдалд мөн өмч хувьчлалын бүтэлгүй үйлдэл шууд нөлөөлсөн. Мөн 1990 -ээд онд төр зөсгийн эрхэнд гарсан амьдрал мэддэггүй зарим хүмүүс Монголд газар тариалан хэрэггүй, тус салбарын бүтээгдэхүүнийг гадаадаас импортлож хангаж байвал болно гэсэн ухуулгыг гадаад орнуудад болон олон улсын байгууллагад хийж, тийм туйлын буруу ойлголтыг төрүүлсэн явдал ч газар тариалангийн салбарын уналтад нөлөөлсөн байв. Сүүлийн хэдэн жилд Төр засгийн дээд байгууллагаас газар тариалангийн салбарт “Атарын гуравдахь аян” нэртэй арга хэмжээ хэрэгжүүлж тус салбарыг сэргээх талаар мэдэгдэхүйц амжилт олж байгаа болно. Гэхдээ 1990 оны өмнөх хэмжээнд хүрэх болоогүй байна.

Зургаад, Шилжилтийн сүүлийн арван жилд барилга, авто тээвэр зэрэг зарим салбарын уналт сэргэсэн, ялангуяа зам барилгын ажил нилээдүй өрнөлттэй явагдсан, худалдаа үйлчилгээний салбар ихээхэн өргөжсөн, бараа таваарын хангамж эрс сайжирсан сайн талтай байгаа болно.

Долоод, Шилжилтийн он жилүүдэд хувийн хэвшил баттай бүрэлдэж, ДНБий 70 гаруй хувийг хувийн хэвшлийн хүрээнд бүтээдэг болсон, үйлдвэрлэл, үйлчилгээний томоохон компаниуд бий болсон явдал нь зах зээлийн тогтолцоо бүтэж бүрэлдсэний нотлогоо юм.

Наймд, Шилжилтийн сүүлийн жилүүдэд макро эдийн засгийн байдал мэдэгдэхүйц сайжирсан хэдий ч, асар өндөр түвшинд хүрсэн ажилгүйдэл, ядуурлын түвшин олигтой буурахгүй байгаа бөгөөд баян, хоосны эрс ялгаа бий болсон явдал нь олон нийтийн анхаарлыг татаж, түгшээсэн хэвээрээ байгаа болно.

Цаашдын төсөөлөл. Сүүлийн үед манай төр засгийн түшээд Монгол улс үсрэнгүй хөгжлийн гараан дээр ирээд байна гэж ярьж бичих болоод байгаа билээ. Тийнхүу "үсрэнгүй хөгжил" гэж сүр дуулиантай тунхаглан зарлахын оронд эдийн засгийн хөгжлийг эрчимжүүлэх гэсэн даруухан чиг баримтлалаар хандах нь илүү зохистой байх болов уу.

Шинэтгэл шилжилтийн хугацаанд бүрэлдсэн нийгэм-эдийн засгийн өнөөгийн байдалд судлагаа шинжилгээ, үнэлэлт дүгнэлт хийсний үндсэн дээр цаашид 
Монгол улсыг хөгжүүлэх урт хугацааны, эхний шатанд 2021 он хүртлэх 10 жилийн хөгжлийн стратеги бодлого, арга замыг тусгасан цогц хөтөлбөрийг боловсруулах шаардлагатай байгаа юм.

Тийм зөвлөмж, саналыг илтгэгч хүмүүн би бээр нилээн хэдэн жилийн өмнөөс тавьж ирсэн бөгөөд уг үйл хэрэгт тус нэмэр болгох үүднээс өөрийн судлагаа, туурвилын материал, санал үндэслэлд тулгуурласан "Монгол улсын хөгжлийн арга зам, төсөөлөл" хэмээх 6 бүлэг, 20 зүйл бүхий ном бичиж 2006 онд нийтлүүлсэн юм.

Улс орны эдийн засаг бол нийгмийн бүхий л асуудлыг шийдвэрлэх, хүн ардын амьжиргааны түвшинг дээшлүүлэх материаллаг эх үүсвэр, гол тулгуур хүчин зүйл байдаг учраас үйлдвэрлэн бүтээх үйл хэргийг өргөтгөн нэмэгдүүлэх үүднээс бодит эдийн засгийн зохистой бүтэц, үйлдвэрлэлийн хүчин чадлыг бүрэлдүүлэх явдлыг л стратегийн гол зорилт болгох шаардлагатай байна. Тэхдээ эдийн засгийн удирдлага зохицуулалт, арга механизмыг оновчтой болгох үйл хэргийг хослон хэрэгжүүлэх явдал нэн чухал байгаа болно.

Монгол улсын эдийн засгийн хөгжилд үндсэн суурь дэвсгэр, хүчин зүйлс болох гурван төрлийн нөөц боломж байгаа юм. Тэдгээр нь хүн амын тоо, ажиллах хүчний нөөц, байгалийн эрдэс баялаг, малын гаралтай түүхий эд юм.

Суурин хүн амын тоо 2010 оны тооллогоор 2,780.8 мянгад хүрсэн, түүнээс хөдөлмөрийн насны хүн ам 1,863.4 мянга, эдийн засгийн идэвхитэй хүн ам 1,147.1 мянга, ажиллагчдын тоо 1,033.7 мянгад хүрсэн байлаа. Нийгмийн хамгаалал, хөдөлмөрийн яам, Үндэсний статистикийн хорооны судлагаагаар 140 орчим мянган хүн ажилгүй байгаа гэсэн тоо гарсан юм. Энэ байдлаас үзвэл, цаашид үйлдвэрлэл, үйлчилгээний салбаруудыг өргөтгөхөд ажиллах хүчний чөлөөт нөөц байгаа болно.

Монгол улсад эрдэс баялгийг олборлох уул уурхай-металлургийн үйлдвэрийг хөгжүүлэх ихээхэн нөөц боломж байгаа бөгөөд тэр нь эдийн засгийн өсөлт хөгжлийн нэг үндсэн салбар болох юм.

Монгол улсын өргөн уудам нутагт бүрэн гүйцэд нарийвчлалтай геологийн судлагааны ажил хийгдэж амжаагүй байгаа хэдий ч, өнөөгийн судлагааны түвшинд 80 гаруй нэр төрлийн ашигт малтмалын 8 мянга гаруй илэрлийг нээснээс 40-өөд нэр төрлийн 500 орчим ордын нөөцийг тогтоосон, улмаар 200-аад ордыг ашиглаж байсан тухай хэдэн жилийн өмнөх мэдээлэл байдаг юм. Монгол орны нутаг дэвсгэрт алт, мөнгө, зэс, молибден, хар төмөр, цайр, хар болон цагаан тугалга, гянт болд, хайлуур жонш, уран, газрын ховор элемент, нүүрс, фоосфорит, анар эрдэнэ, барилгын төрөл бүрийн материал зэрэг 30 шахам төрлийн ашигт малтмалын нөөц судлагдсан байгаа ажээ.

Монгол улсын хувьд мал сүрэг, малын гаралтай бүтээгдэхүүн бол аж ахуй, үйлдвэрлэлийн болон ард түмний амьжиргааны байнгын нөхөн сэлбэгддэг нөөц баялаг юм.

Манай орны таван хушуу мал сүргийн тоо 2007-2009 онд 40-44 сая толгойд хүрсэн байсан бол 2010 оны зуданд 11 сая толгой мал хорогдож 33 сая мал тоологдсон байгаа болно. Мал аж ахуй бол монголчуудын уламжлалт хүнсний бүтээгдэхүүн - мах, сүүний хэрэглээг хангахаас гадна малын ноос ноолуур, хөөвөр хялгас, арьс шир нь хөнгөн аж үйлдвэрийн натурал түүхий эдийн томоохон нөөц болдог юм.

Монгол улсад хэвийн байдлаар бол жилд 10-11 сая ширхэг бог малын арьс, 800 
мянга орчим бодын шир бэлтгэх боломж байгаа юм. Энэ бол төрөл бүрийн арьс ширэн хувцас, гутал, бусад бүтээгдэхүүн үйлдвэрлэж дотоод хэрэгцээг хангахаас гадна экспортод гаргах үйлдвэрийн ихээхэн натурал түүхий эдийн нөөц юм. Мөн жилд 22-23 мянган тонн хонины ноос, 6 мянга орчим тонн ямааны ноолуур, 1.3 мянган тонн тэмээний ноос бэлтгэх боломж байгаа явдал нь нэхмэлийн үйлдвэрийн ихээхэн нөөц байгааг харуулж буй хэрэг юм.

Дээр дурьдсан хөгжлийн асуудлыг шийдэх суурь дэвсгэр болохуйц нөөц боломжийг үндэслэн, бодит эдийн засгийг ирэх 10 жилийн хугацаанд хөгжүүлэх үндсэн зорилтыг дэвшүүлж, томоохон төслүүдийг хэрэгжүүлэх боломжтой гэж бодож байна.

Дотоодын нийт бүтээгдэхүүний ахиухан өсөлтийг хангах, улсын төсвийн орлого, санхүүгийн хуримтлалыг өсгөн аривжуулах, гадаад худалдааны экспортыг нэмэгдүүлэхэд хамгийн жинтэй хувь нэмэр оруулах боломжтой салбар бол аж үйлдвэр юм.

Монгол улсын аж үйлдвэрийн салбарыг хөгжүүлэх талаар өнөөгийн болон ойрын ирээдүйн нөхцөлд эрдэс баялгийн томоохон ордуудыг ашиглах уул уурхайметаллургийн үйлдвэрийг болон малын гаралтай түүхий эдийг боловсруулах хөнгөн аж үйлдвэрийг хөгжүүлэх хоёр үндсэн чиглэл байгаа болно.

Аж үйлдвэрийн салбарыг ойрын ирээдүйд хөгжүүлэхийн тулд дараахь хэдэн томоохон төслүүдийг хэрэгжүүлэх шаардлага, боломж байгаа гэж үзэж байна. Тухайлбал :

1.Уул уурхайн салбарын хувьд зэс, алт, мөнгөний ихээхэн нөөцтэй Оюу толгойн ордыг ашиглах ил, далд уурхай, баяжуулах үйлдвэр байгуулах бүтээн байгуулалтын ажил ид явагдаж байгаа бөгөөд 2013 онд ашиглалтад оруулах төлөвлөгөөтэй байгаа гэдэг нь нийтэд тодорхой байгаа билээ.

Оюу толгой ордыг ашиглах ТЭЗҮ, цогц төлөвлөгөөний дагуу тус ордын ил, далд уурхайнуудын хүдрийн олборлолт жилд 55-58 сая тонн-д хүрэх юм. Баяжуулах үйлдвэрт эхний 3 жилд 27-30 \%-ийн зэсийн агуулгатай 650-700 мянган тонн баяжмал үйлдвэрлэх, 4-6 дахь жилд анхны өргөтгөл хийсний дараа 1,600 мянган тонн баяжмал, хоёр дахь өргөтгөл хийсний дараа зургаа дахь жилээс хойш буюу 2020 оны үед жилд 30 \%-ийн зэсийн агуулгатай 2,300 мянган тонн баяжмал үйлдвэрлэх тооцоотой байгаа ажээ.

2. Монгол улсад өнгөт металлургийн салбарыг хөгжүүлэх түүхий эдийн нөөц боломж байгаа билээ. Эрдэнэтийн уулын баяжуулах үйлдвэрийн зэсийн баяжмалд 110-120 мянган тонн цэвэр зэс агуулагдаж байгаа бол Оюу толгойн үйлдвэр бүрэн хүчин чадлаар ажилласан нөхцөлд 700 мянган тонн хүртлэх хэмжээний металл зэс агуулж байх болно. Оюу толгойн үйлдвэрийн зэсийн баяжмалыг боловсруулахад зэс, алт, мөнгө, молибден зэрэг өнгөт болон үнэт металлыг ялгаруулж авах асар их давуу талтай байх болно. Гагцхүү техник технологийн доод түвшинд зэс ялгаруулах үйлдвэр байгуулбал, чанар муутай зэсийг зах зээл олж борлуулахад төвөгтэй, харин зэсийн баяжмалыг хаана ч борлуулах боломжтой байх тул зэс ялгаруулах үйлдвэрийг нэгд, эдийн засгийн зохих үр ашгийг хангах оновчтой хүчин чадлын хэмжээнд, хоёрт, бүтээгдэхүүний чанар, стандартын өндөр түвшинг хангахуйц тэргүүн зэргийн техник технологитой байгуулах зарчмыг хатуу баримтлах нь зүйтэй юм.

3. Уул уурхайн салбарын хоёр дахь томоохон төсөл болох нийтдээ 6 тэрбум тонн, түүнээс 1.8 тэрбум тонн коксжих нүүрсний нөөцтэй Тавантолгойн ордыг 
ашиглах үйл хэрэг эхлэлийн шатандаа явагдаж байна. Гагцхүү уг ордыг зохистой арга хэлбэрээр, өндөр үр өгөөжтэй ашиглах явдал чухал байгаа юм. Одоогоор дөрвөн хэсгээс бүрэлдэж буй уг ордыг цогцоор нь ашиглах талаар ТЭЗҮ боловсрогдоогүй, хөрөнгө оруулагчдыг сонгож чадаагүй, коксжих нүүрсийг ямар зах зээлд хичнээн хэмжээгээр гаргах, зам тээвэр, цахилгаан эрчим хүчний зэрэг дэд бүтцийн асуудлууд шийдэгдээгүй байна. Тийм байдалд мань мэтийн хүмүүс санаа зовниж байгаа юм.

4. Монгол улсад Газрын тос боловсруулах үйлдвэр байгуулах төслийг нэн яаралтай хэрэгжүүлэх шаардлагатай болоод байна. Монголд газрын тосны бүтээгдэхүүний хангамж 100 хувь гадаадын импортоос хамааралтай байгаа явдал нь үе үе бензин шатахууны хомсдол болох, үйлдвэрлэл, үйлчилгээний ажил үйлсд саад учруулах, гадаад худалдааны үнэ нь байнга нэмэгдэх, улмаар түүний нөлөөгөөр инфляци үүсгэх, цаашид гадаадын хөрөнгө оруулагчид Монголд томоохон төслүүдийг хэрэгжүүлэх талаар итгэл үнэмшлийг сулруулах зэрэг байдалд хүргэж байгаа болно.

Тийм учраас Дархан хотод Монгол улсын бензин шатахууны ойрын ирээдүйн хэрэгцээг бүрэн хангахаар жилд 2 сая тонн газрын тос боловсруулах хүчин чадалтай, тэргүүний техник технологитой, эдийн засгийн өндөр үр ашигтай үйлдвэр байгуулах төслийг Монгол, Японы хамтын ажиллагааны шугамаар шуурхайлан хэрэгжүүлэхээр бэлтгэгдсэн байгаа болно.

5. Мөн Дархан хотод байгаа Хар төмөрлөгийн үйлдвэрийн техник технологийг шинэчлэн, хүчин чадлыг өргөтгөх, уг үйлдвэрийн түүхий эдийн хэрэгцээг хангах зориулалтаар Дархан-Сэлэнгийн бүс нутаг дахь ордын төмрийн хүдрийг боловсруулах үрлэн төмрийн үйлдвэр байгуулах төслийг цогцоор нь хэрэгжүүлэх, уг төслийн ТЭЗҮ-ийг түргэвчлэн боловсруулах шаардлагатай байгаа болно. Уг хар төмөрлөгийн үйлвэрийн цогцолборын хүчин чадлыг, хар металлын дотоодын хэрэгцээ болон гадаадад экспортлох боломжийг харгалзан зохистой хэмжээнд тогтоох нь зүйн хэрэг юм.

6. Монгол улсын хувьд эдийн засгийн ахиухан өсөлтийг хангах, экспортыг нэмэгдүүлэх, ажлын байрыг олшруулах нэг гол үр дүнтэй арга хэмжээ бол мал аж ахуйн гаралтай түүхий эдийг боловсруулах аж үйлдвэрийг сэргээн хөгжүүлэх явдал юм.

Манай оронд жил дутам бэлтгэх боломжтой малын гаралтай түүхий эдийн нөөцийг мөнгөн дүнгээр үнэлж үзвэл 150-160 орчим тэрбум төгрөгөөр тооцогдож байна. Тийм хэмжээний түүхий эдийг бүрэн гүйцэд боловсруулж, эцсийн хэрэглээний бүтээгдэхүүн үйлдвэрлэхэд уг боловсруулах аж үйлдвэрийн нийт бүтээгдэхүүний борлуулалтын хэмжээ 900-960 тэрбум төгрөгт хүрч, түүхий эдийн үнээс 6 дахин нэмэгдэх тооцоо гардаг юм. Тийм болохоор малын ноос ноолуур, арьс ширийг боловсруулах хөнгөн аж үйлдвэрийн салбарыг сэргээн хөгжүүлэх талаар тусгай хөтөлбөр боловсруулж хэрэгжүүлэх нь зүйтэй байна.

7. Монгол улсын хөдөө аж ахуйн салбарыг хөгжүүлэх талаар дараахь хэдэн үндсэн асуудалд анхаарлаа хандууламаар байгаа юм. Тухайлбал :

(1) Мал аж ахуйн хувьд, юуны өмнө мал сүргийг зудын үхэл хорогдлоос аврах малын тэжээл бэлтгэл, тариалалт, үйлдвэрлэлийг сэргээх, малын бэлчээрийг усжуулах, сайжруулалт хийх замаар хүрэлцээг нэмэгдүүлэх талаар Монгол орны байгаль-цаг уурын нөхцөлд тохирсон арга хэмжээг 1990 оны өмнөх үеийн арга туршлагыг бодолцон хэрэгжүүлэх талаар Төр засгаас анхаарч арга хэмжээ авах. 
(2) Газар тариалангийн салбарыг юуны өмнө улаан буудай, төмс, хүнсний ногооны дотоодын хэрэгцээг бүрэн хангах түвшинд хүртэл сэргээхийн тулд тариалалтын нийт талбайг болон услагаатай тариаланг өргөтгөх, ургацыг нэмэгдүүлэх дэвшилтэт арга технологийг нэвтрүүлэх, машин техникээр хангахад чиглэгдсэн иж бүрэн арга хэмжээг тусгай хөтөлбөрийн үндсэн дээр хэрэгжүүлэхэд Төр засгаас тариалан эрхлэгч аж ахуйнуудад туслах.

(3) Зарим бүс нутагт мах, сүүний өндөр ашиг шимтэй үүлдрийн мал, услагаатай тариалан хосолсон үлгэр жишээ аж ахуйнуудыг байгуулах төслийг хэрэгжүүлэх

Хөдөө аж ахуйн салбарын хувьд дээрх хэдэн тоймтой чиглэлийг төр засгийн ойрын ирээдүйн бодлого, зорилт болгох нь зүйтэй байна.

8. Зам тээврийн салбарын хувьд, Таван толгойн коксжих нүүрсний уурхай, зэс ялгаруулах үйлдвэр, Хар төмөрлөгийн цогцолбор, мөн ураны ордыг ашиглах зэрэг Зүүн хойт Ази руу чиглэсэн экспортын зориулалттай томоохон төслүүдийг хэрэгжүүлэх нэг гол нөхцөл болох далайн шинэ гарцад хүрэх зориулалтаар Монголын өнөөгийн магистрал төмөр замаас дорнод хил хүртэл төмөр зам тавих, улмаар тэндээс Япон тэнгис дэх усан замын боомт хүрэх төмөр замд холбогдох төслийг хэрэгжүүлэх явдал улс хоорондын харилцааны дэд бүтцийн хамгийн чухал төсөл болно.

9. Хөгжлийн томоохон төслүүдийг хэрэгжүүлэхийн тулд дэд бүтцийн нэгэн чухал асуудал бол цахилгаан, дулааны эх үүсвэр, шугам сүлжээг бүрэлдүүлэх явдал юм.

Уул уурхайн салбарт, ялангуяа өмнөт бүс нутаг дахь Оюу толгой, Таван толгой, Цагаан суврагын зэсийн ордыг ашиглах уурхай, үйлдвэрүүдийн цахилгааны хэрэгцээг хангах эх үүсвэрийг бий болгох асуудал шийдэгдээгүй байна. Тийм учраас Оюу толгой, Таван толгой тус бүрт дулааны цахилгаан станцуудыг болон Улаанбаатарт цахилгаан, дулааны тав дахь эх үүсвэрийг болон Дарханы Цахилгаан станцыг өргөтгөн шинэчлэх эсвэл шинээр цахилгаан станц байгуулах зэрэг төслүүдийг хэрэгжүүлэх шаардлагатай байгаа болно.

Хөгжлийн хувь заяны хамаарал. Энэхүү илтгэл дэх 9 зүйлээр тоймлогдсон Монгол улсын ойрын ирээдүйн хөгжил дэвшлийн үндсэн зорилт, томоохон төслүүдийг үр өгөөжтэй хэрэгжүүлэхийн тулд юуны өмнө өнөөгийн зарим саад бэрхшээлийг арилгах, тууштай бодлого, хөтөлбөр боловсруулж хэрэгжүүлэх шаардлагатай байгаа юм. Тухайлбал :

1. Өнөөгийн Монголын төр засагт улс орны эдийн засаг, нийгмийг урт хугацаанд хөгжүүлэх шинжлэх ухааны бодит үндэслэл тооцоотой бодлого дутмаг, хуульчилсан хөтөлбөр байхгүй байна. Тийм болохоор эхний шатанд Монгол улсыг 2021 он хүртлэх ойрын ирээдүйд хөгжүүлэх хөтөлбөрийг боловсруулах, түүнд дээрх зорилт, төслүүдийг тусгаж хуульчлан батлах, Улсын Их Хурал, Засгийн газар заавал хэрэгжүүлдэг байх.

2. Эдүгээ Монгол улсын төсвийн орлого хомс, шинэ дутам байгуулагдсан Хөгжлийн банкны хөрөнгийн чадавхи бүрэлдэж амжаагүй, гол төлөв гадаад эзэдтэй Арилжааны банкуудын зээлийн хүү жилд 20-30 хувь байгаа нөхцөлд бүтээн байгуулалтын томоохон төслүүдийг дотоодын хөрөнгийн эх үүсвэрээр санхүүжүүлэх боломжгүй байгаа юм. Тийм учраас стратегийн ач холбогдолтой, эдийн засгийн өндөр үр ашигтай төслүүдэд гадаадын банк, санхүүгийн байгууллагын урт хугацаатай, бага хүүтэй зээл авах, Засгийн газраас зээлийн батлагаа гаргадаг 
болох, гадаадын шууд хөрөнгө оруулалтыг зохистой хэлбэрээр татах, хөрөнгийн бирж дээр хувьцаа гаргах зэргээр хөрөнгийн эх үүсвэрийг бүрдүүлэх чиглэлээр төр засгаас тууштай үйл ажиллагаа явуулах, хувийн хэвшилд дэмжлэг үзүүлэх.

3. Энэхүү илтгэлд зөвлөмж болгож буй хөгжлийн зорилт, төслүүдийг хэрэгжүүлэхэд шаардагдах ажиллах хүчний хэрэгцээг хангах хөдөлмөрийн нөөц тооны хувьд байгаа боловч шилжилтийн он жилүүдэд мэрэгжилтэй ажилчдыг сургаж бэлтгэх явдал туйлын хангалтгүй байсан тул бодит байдал дээр шинээр барьж байгуулах үйлдвэр тус бүрээр мэрэгжилтэй ажиллах хүчнийг сургаж бэлтгэх шаардлага гарах бөгөөд түүнээс төслүүдийг амжилттай хэрэгжүүлэх асуудал хамаарах болно.

4. Төр засгийн дээд байгууллага, яам газруудын удирдах албан тушаалтнуудын ажил хэрэгч чанар, ухамсар хариуцлага сул, мэрэгжил, туршлага дутмаг, шийдвэр гаргах чадвар мөхөс зэрэг байдал нь хөгжлийн томоохон төслүүдийг хэрэгжүүлэхэд саад тотгор болох дараахь сөрөг нөлөө хамааралтай байгаа билээ. Тухайлбал :

(1) Улсын Их Хурлын болон Засгийн газрын тогтоол шийдвэрийг хэрэгжүүлэх хариуцлага юуны өмнө төр засгийн байгууллагын албан тушаалтнуудад туйлын дутмаг байгаа учраас стратегийн тэргүүлэх ач холбогдолтой бөгөөд бүрэн бэлтгэгдсэн чухал төсөл ч хэрэгжихгүй хэдэн жилийн хугацааг өнгөрүүлж байдаг юм. Тийм байдлын жишээ нь, Дархан-Уул аймагт Газрын тос боловсруулах үйлдвэр байгуулах тухай 2008-2010 онд УИХ-аас тогтоол 3 удаа, Засгийн газрын тогтоол 2 удаа гарсан хэдий ч өнөө хүртэл үйлдвэрийн барилгын ажил эхлээгүй байна.

(2) Монголын Төр засгийн дээд байгууллагын удирдлагын шийдэмгий бус, цалгар байдлаас шалтгаалан, улс орны хөгжлийн томоохон асуудлын шийдэл ихээхэн удааширдаг, түүнээс болж олон он жилийн хугацааг өнгөрүүлдэг, улмаар санхүү, эдийн засгийн үр өгөөжийн асар их боломжийг алддаг зохисгүй байдал хэвшил болсон байгаа юм. Тийм байдлаас болж сүүлийн хориод жилд нэг ч томоохон үйлдвэр байгуулагдаагүй өнгөрсөн байв. Мөн нэгэн тодорхой жишээ бол Оюу толгой төслийг хэрэгжүүлэх Хөрөнгө оруулалтын гэрээ байгуулах яриа хэлцэл хэдэн жилийн турш сунжирч байж 2009 оны сүүлчээр шийдэлд хүрсэн явдал мөн.

(3) Манай улсын төр засгийн түвшинд томоохон төслийг хэрэгжүүлэх арга хэлбэр, нөхцөл боломжийг иж бүрнээр авч үзэх явдал дутагдалтай байгаа явдал төслүүдийг үр өгөөжтэй хэрэгжихэд сөрөг нөлөөтэй байж болох юм. Тийм байдлын өнөөгийн жишээ бол Оюу толгой ордын уурхай, баяжуулах үйлдвэр ойрын үед ашиглалтад орно гэж байхад одоо хүртэл цахилгаан хангамжийн асуудал нь шийдэгдээгүй байна. Оюу толгойд 400 мВт-ын хүчин чадалтай цахилгаан станц барих ТЭЗҮ-ийг Айвенхоо Майнз компани, Японы талаар хийлгэсэн боловч уг цахилгаан станцыг барих зөвшөөрлийг Монголын Эрдэс баялаг, эрчим хүчний яам олгоогүй байгаа нь гайхал төрүүлж байгаа юм. Түүнчлэн Таван толгойн ордын зарим хэсэгт нүүрс олборлох ажил үйлс хийгдэж эхлээд байхад мөн төмөр зам, цахилгаан станц барьж байгуулах асуудал нь шийдэгдээгүй байгаа бололтой юм.

(4) Монголын төр засгийн өнөөгийн түвшинд мэрэгжлийн зохих түвшинд үндэслэл тооцоо хийгдээгүй асуудлыг өнгөц хийсвэр ойлголтоор тунхаглан нийтэд зарладаг ноцтой дутагдал байгаа явдал нь бодит эдийн засгийн асуудлын талаар төөрөгдөлд хүргэж болзошгүй гэдгийг анхаарууштай байгаа юм. Жишээ нь сүүлийн жилүүдэд аж үйлдвэрийн парк гэсэн хиймэл томъёололын нэрээр, Сайншандад 7-12 томоохон үйлдвэр байгуулж, 260-300 мянга орчим ажлын байрыг шинээр бий болгох тухай ямар техник-эдийн засгийн үндэслэл тооцоотой болох нь тодорхойгүй 
бөгөөд огт ойлгомжгүй асуудлыг үе үе сонин хэвлэлд бичсэн явдал тааралдаж байгаа болно. Гэтэл регионал эдийн засаг, үйлдвэрлэх хүчний хөгжил байршлын арга зүй, хүчин зүйлсийн үүднээс авч үзвэл Сайншандад тийм олон үйлдвэр байгуулах боломжгүй гэдэг нь мэдээжийн хэрэг баймаар юм.

5. Өнөөгийн нөхцөлд Төр засгийн дээд албаны хүмүүс, улс үндэстний эрх ашгийн том асуудалд хувийн ашиг сонирхолын үүднээс явцуу байдлаар хандахгүй байх, стратегийн бодлогын том асуудлыг компанийн менежерийн бизнессийн үүднээс тайлбарлахгүй байх явдал нь Монгол улсын цаашдын хөгжлийн зарчмын асуудлуудыг оновчтой шийдвэрлэх, томоохон төслүүдийг амжилттай хэрэгжүүлэхэд зохих нөлөө хамааралтай байх болно.

6. Монголын төрөөс эдийн засаг, нийгмийг, судлагаа шинжилгээний үндсэн дээр, мэрэгшлийн байнгын өндөр түвшинд боловсрогдсон цогц бодлого, төлөвлөлтийн дагуу хөгжүүлэхийн тулд Эдийн засгийн төв байгууллагыг болон Эдийн засгийн хүрээлэнг нэн яаралтай байгуулах шаардлагатай байна. Тэхдээ Эдийн засгийн төв байгууллага нь Улсын Их Хуралд шууд харьяалагддаг, яамдын үйл хэргийг хөгжлийн бодлого, төлөвлөлтийн асуудлаар нэгтгэн зохицуулдаг эрх үүрэгтэй байх, тус байгууллагын дарга нь Улсын Их Хурлын байнгын Тэргүүн дэд дарга бөгөөд Үндэсний Аюулгүй байдлын Зөвлөлийн гишүүн байх нь зүйтэй юм. Мөн Эдийн засгийн хүрээлэнг Эдийн засгийн төв байгууллагын болон Шинжлэх Ухааны Академийн давхар харьяалалд байгуулбал зохино.

Монгол улсын хөгжлийн томоохон төслүүдийг үр өгөөжтэй хэрэгжүүлэх үйл хэрэг нь эцсийн дүндээ төр засгийн дээд байгууллагын удирдах албан тушаалтнуудын улс орны эрх ашгийн төлөөх ажил хэрэгч чанар, хариуцлагатай зүтгэл, бодит сэтгэлгээ, мэдлэг туршлагаас хамаарах тул эдүгээ манай улсын төр засгийн байгууллагад байгаа өнөөгийн ноцтой алдаа дутагдлыг засч залруулах явдал нэн чухал бөгөөд ихээхэн нөлөө хамааралтай байх болно. 